\title{
Traffic jam on the music highway: Is it a reproduction or a performance?
}

\author{
MICHAEL A. EINHORN* \\ Intecap Inc. \\ and \\ LEWIS KURLANTZICK \\ University of Connecticut, School of Law
}

\begin{abstract}
The American copyright system separately protects the sounds in music recordings and the words and music of the underlying musical composition upon which they are based; separate rights are further defined for the reproduction and public performance of both the recording and the composition. The consequences of copyright fragmentation are now quite disturbing, as digital technology produces a breakdown and conflation of legal categories that were meaningful in the analog era; the same act of digital transmission can be viewed under U.S. law as reproduction and distribution of copies on the one hand and public performance or display of the work on the other. Since these rights are controlled by different parties and agents, the complexity of the system leads to a "copyright thicket". This article attempts to break the gridlock with an economic analysis based on the need for allocative efficiency, transaction minimization, administrative streamlining, and technological innovation.
\end{abstract}

\section{Introduction}

The American copyright system separately protects the sounds in music recordings and the words and music of the underlying composition upon which they are based; separate rights are defined for reproduction and public performance of each work. Consequently, as Lemley (1997) notes, at least four distinct rights are implicated in the use of any piece of recorded music in digital audio. Some of these complementary rights are under the exclusive control of one owner, while others can be regulated by or are under the control of an independent second owner. Moreover, different institutions perform different administrative roles (Towse, 1999). This fragmentation of copyright yields duplicative regulation and negotiation, with a corresponding increase in the costs of administration.

\footnotetext{
* Contact author. Senior Advisor, Intecap, Inc., New York, NY. E-mail address:

meinhornphd@ @otmail.com. We wish to thank Jeffrey Fritz for able research and Dean Nell Newton for generous summer research support. An earlier version of this article appeared in the Journal of the Copyright Society.
} 
The consequences of fragmentation are disturbing in the digital age, as digital technology produces a breakdown and conflation of legal categories that were meaningful in the analog era. By statutory standards, every audio transmission on the Internet now involves making reproductions and wired performances of both the recording and its underlying composition (Karjala, 2001). Consequently, the same act can be viewed as a reproduction and distribution of copies on the one hand, and a public performance or display of the work on the other. ${ }^{1}$ Since these rights are controlled by different parties and agents, the complexity of the system leads to a gridlock of control that may hinder development.

Moreover, there is a spectrum of user access between permanent reproduction and instantaneous performance that incorporates many intermediate points (Ginsburg, 2002). In this context, the 1996 WIPO Copyright Treaty $^{2}$ and the WIPO Performances and Phonograms Treaty ${ }^{3}$ established "making available rights" that cover the exclusive rights of writers, performers and labels to make - or not make - musical works and recordings available at a time and place selected interactively by an individual listener. Noninteractive services are not included within the "making available" concept but rather would be covered by rights to remuneration for broadcasting and communication to the public. ${ }^{4}$

The confluence of new technology and content has produced serious conflicts among the actors in the digital music industry - composers, publishers, record companies, performing artists, website operators, and online music retailers. Indeed, these conflicts extend to disputes within groups (such as between performing rights societies, which represent composers and music publishers, and mechanical rights organizations, which represent composers and music publishers) and fractious litigation between long-time allies (one example is the songwriters' and music publishers' infringement suit against Universal Records' website ${ }^{5}$ ).

The clashes are rooted in disagreements about a number of policy questions including the proper scope of the exemption for ephemeral recordings, the desirable definition of the limits of the performance and reproduction interests, the number of licenses to be required of an Internet music distributor, and the appropriate treatment of content loaded into a computer's random access memory. The answers given to these questions will, of course, have substantial economic consequences for those involved in the online dissemination of digital music and significant impact on the relative efficiency of the structure in which they operate. A social concern is that the present framework of complex rights of control may make it very difficult for Internet operators to make music

\footnotetext{
${ }^{1}$ The idea of digital transmission obscures the boundaries between broadcasting and distribution of sound recordings. The accepted terms of description (and prescription) of standard modes of exploitation of music (reproduction and performance) do not translate well to contemporary digital uses, which are more accurately described in terms of a continuum marking extent of access. This upheaval in terminology complicates policy analysis. See Ginsburg (2001) and Lemley (1997).

${ }^{2}$ World Intellectual Property Organization Copyright Treaty, Art. 8.

${ }^{3}$ World Intellectual Property Organization Performances and Phonograms Treaty, Art. 10, 14. Both treaties were adopted on December 20, 1996 at a WIPO Diplomatic Conference on Certain Copyright and Neighboring Rights Questions. The United States signed the treaties on April 12, 1997, and the Senate ratified them on October 21, 1998.

${ }^{4}$ See supra note 3, Art. 15.

${ }^{5}$ See Rodgers \& Hammerstein Org. v. UMG Recordings, Inc., No. 00 Civ. 9322, 2001 U.S. Dist. LEXIS 16111 (S.D.N.Y. Sept. 25, 2001).
} 
transmissions legally, even if their activities come within a copyright compulsory license or exemption. In the remainder of this article, we suggest the policy considerations that should inform analysis of these questions.

In addition to difficulties posed by statutory and judicial definition, there is now no commonly accepted method for pricing related rights in a consistent manner. Rate Courts for performing rights and arbitration panels for mechanical rights now set rates in their respective domains using historical methods and benchmarks that do not correspond. Collecting societies make contending claims, cyber-developers are confounded by the complexity of the rules, and songwriters and composers who create music lack legal standing in administrative hearings.

This article brings economic analysis to bear on the topic. The primary concern for any economic analysis is market performance, as manifested in allocative efficiency, transactions costs, and technological progress. First, economically efficient licensing should ensure that copyright administration favors no one delivery method over another. As a practical matter, the relative price ratio between two substitute technologies for delivering music should not be distorted by the presence of asymmetric copyright charges. Second, transaction costs can be reasonably economized by "one-stop shopping" and reduced administration. Since multilateral negotiations and administrative hearings are expensive, the system should convey necessary usage rights through a minimum of transactions. Third, the copyright process and the resulting license costs are among the costs imposed upon new businesses in digital markets. This article will advocate a number of reforms for streamlining the American copyright system to protect the people who create music, the marketers who promote it, and the consumers who buy it.

\section{The Structure of Music Copyright}

Copyright in musical compositions and sound recordings is now secured by the Copyright Act of 1976, the principal provisions of which became effective on January 1, 1978. ${ }^{6}$ The use of recorded music implicates two separate copyrights - the music and lyrics of the underlying composition and the sound recording of the performance of the composition. For example, when Madonna recorded Don McLean's "American Pie", the record label owned rights in the sound recording, while McLean owned rights in the song. Similarly, when George Harrison composed the song "Here Comes The Sun," he authored a musical work protectible by copyright law. In contrast, a sound recording is a fixation of a performance of an artist playing and singing a musical composition. Thus, when The Beatles went into the studio to perform "Here Comes The Sun," the recording of that session produced a sound recording.

The owner of the copyright in the musical composition, generally the music publisher, controls the assignment of rights in the work. It has the right to license mechanical reproduction/distribution and public performance of the words and music. The owner of copyright in the sound recording, generally the record label, controls similar (but not identical) rights in the record imprint; it has a corresponding right to reproduce and a limited right to perform sounds captured in the recording. The owner of each copyright is

\footnotetext{
${ }^{6} 17$ U.S.C. sec. 101-1332 (2000).
} 
compensated through different legal arrangements, which may involve yet more agents and administrative bodies. ${ }^{7}$

\subsection{Musical Compositions}

Section 106 of the Copyright Act grants four exclusive rights to composers who create tangible copies of original musical compositions. ${ }^{8}$ These rights include:

- The right to reproduce the copyrighted work in copies or phonorecords;

- $\quad$ The right to prepare derivative works based on the copyrighted work;

- The right to distribute copies or phonorecords of the copyrighted work to the public by sale or other transfer of ownership, or by rental, lease, or lending; and

- The right to perform the copyrighted work publicly.

The right to reproduce copyrighted musical compositions on tapes or discs, as well as the additional right to distribute copies to the public, is commonly called the mechanical right. ${ }^{9}$ The publisher has exclusive authority to license first-time reproductions of all songs in its catalog. Second uses are subject to compulsory licenses.

Mechanical royalties for the use of compositions on physical CDs are generally collected from record labels by mechanical rights organizations (MROs), most prominently the Harry Fox Agency (HFA). ${ }^{10}$ Royalties are based on the number of physical imprints made of the work. After deducting a small percent for administrative expenses, the MROs return collected moneys to publishers, who are responsible for paying writers their contracted share. Writer-publisher shares can be bilaterally negotiated and are open to competition, ${ }^{11}$ and particularly successful writers may become their own publishers.

Once authorized phonorecords ${ }^{12}$ of a composition are publicly distributed, subsequent performers may record the same work subject to compulsory (or statutory)

\footnotetext{
${ }^{7}$ The exclusive rights to reproduce and to publicly perform copyrighted works are the rights which bear centrally on Internet music transmissions. Clearly, the transmission of recorded musical performances over the Internet involves sending both the sound recording and the musical work embodied in that recording. Since American law affords different rights and limitations to musical works and sound recordings, the complexity of the copyright implications of such transmissions rises, particularly when rights in the works are owned or administered by different parties. This intricate structure produces serious legal and administrative difficulties which demand attention.

${ }^{8} 17$ U.S.C. sec. 106 (2000).

${ }^{9}$ The terms "mechanical right" and "mechanical license" are historically derived from the time when records were mechanically and not electronically reproduced. The right to license the reproduction of music on television, video, and motion picture soundtracks is the synchronization right. In addition, the copyright owner has the right to make derivations based on his work.

${ }^{10} \mathrm{HFA}$ is the music publishing industry's principal clearinghouse for the administration of mechanical rights licenses. Unlike the performing rights societies, HFA is only a collection agency and does not negotiate individual contracts. It files petitions and appears in arbitration hearings in the Copyright Office that involve compulsory mechanical royalties.

${ }^{11}$ That is, independent publishers may compete for new writers by offering high royalty shares.

1217 U.S.C. sec. 101 (2000): “'Phonorecords' are material objects in which sounds ... are fixed by any method now known or later developed, and from which the sounds can be perceived, reproduced, or otherwise communicated, either directly or with the aid of a machine or device. The term 'phonorecords' includes the material object in which the sounds are first fixed."
} 
licenses, established by section 115 of the Copyright Act. ${ }^{13}$ Under statutory licensing, performing artists may record new renditions of previously recorded compositions at administratively-prescribed "fair" fees ${ }^{14}$ without the need to secure express permission from the music publisher (see Lessig, 2001, pp.108-110 for examples of striking a balance between compensation and control). Resort to the compulsory licensing device is often grounded in a concern about transaction costs. The fear is that when transaction costs are high, an otherwise desirable exchange may not occur. A compulsory license, and fair transfer price reflecting the value of the protected work, can presumably be used to facilitate an outcome that is socially productive when positive transaction costs block an efficient exchange (Leaffer, 1999, pp.288-289). Compulsory licensing confers a reproduction and distribution privilege only in the musical composition, not in the sound recording as well. Thus, for example, if one wished to duplicate and sell compact discs of The Beatles' recording of "Here Comes The Sun," one would have to negotiate permission from the copyright proprietor of the sound recording, and he would be free to refuse permission or to charge any fee he saw apt for that permission.

Section 106 also empowers the copyright owner to receive compensation for a work performed in a public forum or medium. Under section 101, to "perform" a musical composition (outside of audiovisual applications) is to "recite, render, play, dance, or act it, either directly or by means of any device or process." "To perform ... a work "publicly" means

(1) to perform ... it at a place open to the public or at any place where a substantial number of persons outside of a normal circle of a family and its social acquaintances is gathered; or

(2) to transmit or otherwise communicate a performance ... of the work to a place specified by clause (1) or to the public, by means of any device or process, whether the members of the public capable of receiving the performance...receive it in the same place or in separate places and at the same time or at different times.

Clearly, the second part of this definition is more significant for Internet transmissions, where streaming, and even downloading, to one listener in a private home may now constitute a public performance.

\section{$3 \quad$ Performance Redux}

Rights for the public performance of compositions in audio, non-dramatic presentations ("small performing right") are almost universally conveyed through licenses granted by the

\footnotetext{
${ }^{13} 17$ U.S.C. sec. 115 (2000). Section 115 creates an exception to both the reproduction and distribution rights by granting third parties a nonexclusive license to make and distribute phonorecords of nondramatic musical works. If arbitrated, rates are established by a Copyright Arbitration Royalty Panel. Compulsory licensing enables secondary users to access works without negotiation, reducing transaction costs. This license requires compliance with certain procedural requirements and payment of a fee established by the Copyright Office. Because the arrangement is more efficient, record companies, in practice, obtain mechanical form licenses for cover recordings from the Fox Agency, licenses which are derived from the statutory compulsory license, rather than rely on the provisions of section 115.

${ }^{14}$ At the time of enactment of the Copyright Act of 1976, section 115 set the statutory fee at 2.75 cents per record and provided for periodic adjustment of this prescribed royalty amount in a public proceeding. At present, the mechanical royalty fee under the compulsory license is the larger of 7.55 cents or 1.45 cents per minute. Increases are scheduled for 2002, 2004, and 2006. See 37 C.F.R. sec. 255.3 (2001).

${ }^{15} 17$ U.S.C. sec. 101 (2000).
} 
nation's three performing rights organizations (PROs) - the American Society of Composers, Authors, and Publishers (ASCAP), Broadcast Music, Inc. (BMI), and SESAC $^{16}$ - which can license all musical works registered in their respective catalogs. Licenses are non-exclusive, meaning that the writer has the authority to license his individual work directly for any particular use. Virtually all music publishers and professional songwriters are members of or affiliated with a performance right society. These collective organizations function to enforce the exclusive right of the copyright owner of a musical work publicly to perform that work.

To this end, the societies sell licenses, collect fees, monitor unauthorized users to discover copyright violations, bring infringement actions when unlicensed use is discovered, take samples to determine the relative frequency with which various compositions are used, and, after deducting operating expenses, distribute revenues to composers and music publishers and their heirs and successors. They also enter into reciprocal arrangements with foreign collecting societies to collect and distribute royalties earned in the home country to foreign rights-holders and to receive and distribute moneys earned abroad to rights-holders in the home country. The history of the performing rights industry reveals the many analytical and organizational problems posed by these tasks.

Each PRO generally issues to broadcasters blanket licenses that enable the licensee to perform all catalogued works. ${ }^{17}$ License fees at all three organizations are established in a parade of negotiations that involve individual or groups of licensees. If the parties are unable to agree on a fee within sixty days of receipt of the initial application at ASCAP or BMI, the potential user may request the federal district court for the Southern District of New York to determine a reasonable fee. These independent Rate Courts enforce the terms of two antitrust Consent Decrees that ASCAP and BMI separately negotiated with the United States Department of Justice. ${ }^{18}$

There are four important microeconomic issues related to the performing rights industry. First, the negotiation and administration of public performance rights currently represents a separate regulatory substrate that operates independently of the Copyright Office. For digital transmissions, Rate Courts do not have a common set of rate-making procedures that are congruent with related rights administered by the Copyright Office, including mechanical and sound recording performance rights. ${ }^{19}$ Problematically, in a digital age, rates established for disparate rights may now affect more seriously the demand for related services and the market structure of the music industry.

Second, songwriters and publishers have limited standing in the legal process. By law, Consent Decrees may be amended only with the consent of the signing parties and permit full legal standing to address proposed changes only to the collecting society and

\footnotetext{
16 The acronym no longer is meaningful.

${ }^{17}$ Another option includes licensing of individual programs ("per program license"), complemented by an add-on license to cover commercial music.

${ }^{18}$ United States v. Am. Soc'y of Composers, Authors and Publishers, 1950 Trade Cas. (CCH), II 62,595 (S.D.N.Y. 1950); United States v. Am. Soc'y of Composers, Authors and Publishers, Second Amended Final Judgment, 2001 WL 1589999, 2001-2 Trade Cas. II 73, 474 (S.D.N.Y. 2001); United States v. Broadcast Music Inc., 1966 Trade Cas. (CCH) II 71,941 (S.D.N.Y. 1966). Under the procedure outlined in the consent decree that establishes judicial supervision over ASCAP's prices ASCAP has the burden of proving to the federal district court the reasonableness of its proposed fee. The term "Rate Court" in the text refers to this district court.

${ }^{19}$ See 17 U.S.C. sec. 114-115 (2000).
} 
the Department. ${ }^{20}$ Only the Justice Department or the signing rights organization may petition for an interpretation of the Decree. Ironically, the writers, publishers, and licensees who create, market, and use the copyrighted music have standing in court only within the narrow definition of the specific Decree and cannot appeal any term that the Department and the performing rights organization have negotiated. ${ }^{2}$

Third, the Justice Department continues to voice antitrust concerns. ${ }^{22}$ Indeed, the Department noted, "[T]echnologies that allow rights holders and music users to easily and inexpensively monitor and track music usage are evolving rapidly ... and may erode many of the justifications for collective licensing of performance rights." ${ }^{23}$ Most recently, the Justice Department, ASCAP, and its affiliates battled to yet another modification of its Consent Decree that further restricts ASCAP's licensing arrangements. ${ }^{24}$ Newly implemented procedures would make smaller licenses on programs and webcast segments more competitive with "all-or-nothing" blanket deals that previous courts sought to protect. ${ }^{25}$ In a supporting memorandum, the Department articulated its ongoing frustration at the state of competition in the performing rights industry. ${ }^{26}$ In unambiguous language, the memorandum reported (at note 10):

The Department is continuing to investigate the extent to which the growth of [digital] technologies warrants additional changes to the [Consent Decrees], including the possibility that the [performing rights organizations] should be prohibited from collectively licensing certain types of users or performances.

\footnotetext{
${ }^{20}$ Consent Decrees must be interpreted within their plain meaning, are not modifiable by the Court, and are adjusted only with the bilateral consent of the signing parties. See United States v. Atl. Refining Co. 360 U.S. 19 (1959); Suarez v. Ward, 896 F.2d 28 (2d Cir. 1990); Berger v. Heckler, 771 F.2d 1556 (2d Cir. 1985).

${ }^{21}$ Licensee standing was denied in United States v. Am. Soc'y of Composers, Authors and Publishers, 208 F. Supp. 896 (S.D.N.Y. 1962), aff'd, 331 F.2d 117 (2d Cir. 1964); United States v. Am. Soc'y of Composers, Authors and Publishers, 708 F. Supp. 95 (S.D.N.Y. 1989). Writer standing was denied in United States v. Am. Soc'y of Composers, Authors and Publishers, 708 F. Supp. 95 (S.D.N.Y. 1989); United States v. Am. Soc'y of Composers, Authors and Publishers, 739 F. Supp. 177 (S.D.N.Y. 1990); United States v. Am. Soc'y of Composers, Authors and Publishers, 914 F. Supp. 52 (S.D.N.Y. 1996).

${ }^{22}$ The Supreme Court's application of the antitrust rule of reason and its rejection of a challenge to BMI's license practices involved recognition of the potential administrative savings from blanket licensing. BMI v. CBS, 441 U.S. 1, 22 (1977), (Stevens, J., dissenting). However, that recognition was conditioned upon the presence of imperfect monitoring technology in the analog world. The Court noted that "changes brought about by new technology or new marketing techniques might also undercut the justification for the practice." ${ }^{23}$ Memorandum of the United States in Support of the Joint Motion to Enter Second Amended Final Judgment, at note 8, United States v. Am. Soc'y of Composers, Authors and Publishers (S.D.N.Y. 2001) (Civ. No. 41-1395). A desirable openness could be achieved if digital performance rights for musical compositions were removed from the coverage of the Consent Decrees and reassigned to the Copyright Office where the corresponding rights in webcast sound recordings are now administered and arbitrated. Under its administrative structure, the Copyright Office could issue Notices of Inquiry and Proposed Rulemaking that would invite comments from all affected parties, and necessarily grant equal legal standing to each in administrative hearings. License fees for statutory licenses could be determined periodically in Copyright office arbitrations. And transactional economies would be possible if one monitoring contractor, such as SoundExchange, were empowered to administer performance rights for both compositions and sound recordings and to split royalties among claimants according to administrative rules.

${ }^{24}$ United States v. Am. Soc'y of Composers, Authors and Publishers, Second Amended Final Judgment, supra note 37.

${ }^{25}$ See, e.g., U.S. v. ASCAP, 1993 Copyright L. Dec. 26, 335 (S.D.N.Y. 1993), at 231 ("we are unlikely to see a rush of stations seeking to utilize [a non-blanket alternative] as to impose undesirable burdens and inefficiencies on the functioning of the music licensing market.").

${ }^{26}$ Memorandum, supra note 23.
} 
Finally, the respective domains of mechanical and performance rights may legally overlap as the same transmission can be classified as both a public performance and a mechanical reproduction (Lemley, 1997, pp.573-574). Performing rights advocates claim all transmitted compositions are public performances and therefore entitle them to compensation. Simultaneously, mechanical rights advocates claim that all transmitted compositions necessarily involve incidental reproductions that are subject to their control. With both groups claiming due copyright payment for the same transmissions, one copyright authority (and music service provider) famously termed the outcome an example of "double dipping".

\section{Sound Recordings}

The Copyright Act extends copyright protection to sound recordings, as distinct from the underlying compositions. ${ }^{27}$ However, that protection, as originally enacted, was limited to the exclusive rights of reproduction and distribution. A public performance right was not granted to the proprietors of sound recordings. Accordingly, stations that played recorded music paid copyright royalties to writers and publishers of musical compositions, but not to the artists and labels that produced the record. ${ }^{28}$ For several decades, record labels unsuccessfully petitioned Congress to grant a public performance right in sound recordings comparable to that for musical works. ${ }^{29}$

In 1995, record companies secured some performance right protection with respect to digital audio transmission ${ }^{30}$ with the passage of the The Digital Performance Rights in Sound Recordings Act of 1995 (DPRSRA). ${ }^{31}$ The Act amended section 106 of the Copyright Act to grant the owner of the sound recording copyright the exclusive right "to perform the copyrighted work publicly by means of a digital audio transmission." ${ }^{32}$ The DPRSRA also amended section 114 of the Copyright Act to establish appropriate limitations on and exemptions from this transmission right. ${ }^{33}$ In 1998, Congress passed the

\footnotetext{
${ }^{27}$ The Copyright Act defines "sound recording" as a work that results "from the fixation of a series of musical, spoken, or other wounds ... regardless of the nature of the material subjects, such as disks, tapes, or other phono records, in which they are embodied." 17 U.S.C sec. 101 (2000).

${ }^{28}$ Presumably, broadcast performances promote record sales that otherwise would not take place. See, e.g., S. Rep. No. 104-128, at 14-15 (1995).

${ }^{29}$ For a brief summary of the history of legislative treatment of the issue, see S. Rep. No. 104-128, at 1-4 (1995). For a discussion of policy arguments against recognition of such a right, see Bard and Kurlantzick (1974).

${ }^{30}$ A "digital audio transmission" is a digital transmission that embodies a sound recording. 17 U.S.C. sec. 114(j)(5) (2000).

${ }^{31}$ Pub. L. No. 104-39, 109 Stat. 336 (1995). For a comprehensive account of the legislative history of the Act and a highly detailed description of its terms, see Leach (2000).

3217 U.S.C. sec. 106(6) (2000).

${ }^{33} 17$ U.S.C. sec. 114, 115 (2000). The law grants copyright owners of sound recordings the right to authorize certain digital transmissions of their works, including interactive digital audio transmissions, and to be compensated for others. The scope of the copyright proprietor's right varies with the kind of digital transmission. Most non-interactive transmissions are subject to statutory licensing at rates to be negotiated or, if necessary, arbitrated. Radio stations maintain a performance exemption for over-the-air digital broadcasts and do not pay copyright royalties to the owner of the sound recording copyright. Generally, the law exempts certain types of digital performances entirely so that no licenses at all are necessary; grants statutory licenses for certain other types of digital performances so that the license fee is set by Copyright
} 
Digital Millenium Copyright Act (DMCA), which further amended sections 114 and 115 of the Act. ${ }^{34}$ The law now grants sound recording producers the right to be compensated for public performance of certain digital audio transmissions of their works, ${ }^{35}$ though sometimes under statutory rates. ${ }^{36}$ Potential licensees include music subscription services, satellite radio, webcasters, and Internet music providers that "make content available" to individual listeners.

Digital music can be accessed in two general ways, downloading and streaming. In downloading, a permanent and usable copy of the audio file is transmitted and stored on the receiving machine's hard drive. After download, the recipient can either play it back through the computer's sound system or "burn" (i.e., copy) it to another storage medium, such as a recordable CD.

Streaming technologies permit users to receive desired content and play it with a few seconds delay. However, since no corresponding copy is made on hard drive, no storage occurs. If the user wants to hear the music again, she must re-stream it from her source. Depending on whether song choice is exercised at user or provider discretion, streaming can be interactive ${ }^{37}$ or non-interactive. The former has the potential of providing services commonly known as "audio-on-demand," "pay-per-listen", or "celestial jukeboxes" that are a proper component of the "making available" right that is protected by the WIPO Treaties of 1996. These services permit listeners to obtain a direct, time-certain transmission of a specific recording.

Section 114(d) of the Copyright Act, then, establishes a carefully graduated threetier structure for governing transmissions through exemptions, statutory licenses, and exclusive rights. ${ }^{38}$ Facing a technology change that could allow music delivery without purchase of $\mathrm{CD}$ or tape, Congress aimed to protect sound recording owners against commercial displacement of sales from downloading and streaming services that preserved the option value of personally owned music. ${ }^{39}$ Furthermore, non-interactive webcasting had the additional potential of displacing the new digital services that would provide downloads and streams on-demand. We shall highlight the key elements of Section 114(d) in so far as they relate to the discussion that follows:

Office proceedings rather than by private negotiations; and requires licenses to be secured directly from record companies, through negotiations, only for the remaining types of digital performances.

${ }^{34}$ Pub. L. No. 105-304, 112 Stat. 2860 (1998). For criticism of the laboriousness and complexity of this scheme of exemptions, statutory licenses, and voluntary licenses, see Nimmer (2000, p.189).

35 17 U.S.C. sec. $114(\mathrm{~d})(1)-(3)(2000)$.

3617 U.S.C. sec. 115 (2000).

${ }^{37}$ An "interactive" stream is "one that enables a member of the public to receive ... a transmission of a particular sound recording ... which is selected by or on behalf of the recipient." 17 U.S.C. sec. 114(j)(7) (2000). The definition seeks to identify a service as interactive according to the amount of influence a member of the public has on the selection and performance of a particular sound recording.

${ }^{38}$ Nonsubscription digital broadcast transmissions are treated as analog radio transmissions had been. Record producers are granted neither control nor compensation. Subscription digital transmissions are subject to a statutory license, provided the transmitting entity meets the eligibility conditions. Finally, the copyright owner enjoys full control over interactive transmissions as well as subscription transmissions that do not meet the eligibility requirements for a statutory license.

${ }^{39}$ H.R. Rep. No. 104-274 (1995). Congress aimed to compensate sound recording copyright owners for technology-driven sales displacement. Accordingly, the differential treatment of kinds of users with respect to sound recording performance liability - exemption, eligibility for compulsory license, full liability reflects a judgment about the probable adverse effects of each on sales of sound recordings. 


\subsection{Exemptions}

Under section 114(d)(1), radio stations maintain a performance exemption for over-the-air broadcasts and do not pay copyright royalties to the copyright owner of the sound recording. Exemptions are now limited to non-subscription broadcast transmissions and, to a degree, their retransmissions. To be exempt, the transmission must be non-interactive and aimed at the general public rather than individual subscribers. Performances of sound recordings made on simultaneous webcasts of over-the-air broadcasts are not exempt and are governed by the terms of the statutory licenses described in Section 4.2. ${ }^{40}$ A more thorough delineation of exemptions and definitions appears in the Act. ${ }^{41}$

\subsection{Statutory Licenses}

Under section 114(d)(2), specified non-interactive Internet webcasts may be eligible for a compulsory (or statutory) license that avoids the need for direct negotiation with the recording label. Statutory licensing may be subject to eligibility requirements ${ }^{42}$ that attempt to insure that the transmission does not displace sales of CDs, downloads, and interactive music services. If copyright owners and potential users cannot agree on a negotiated license rate, any interested party may petition the matter to a Copyright Arbitration Royalty Panel (CARP) for a determination of what constitutes a reasonable rate for a compulsory license for the intended use. ${ }^{43}$ Reflecting economic awareness, rates and terms should clearly reflect analogues that would have been negotiated between a willing buyer and willing seller in a competitive marketplace. Furthermore, the panel must base its decision on economic, competitive and programming information presented by the parties,

\footnotetext{
${ }^{40}$ In December 2000, the Copyright Office denied an exemption to simultaneous retransmissions made by over-the-air radio broadcasters. The Office concluded that the simultaneous transmission of an over-the-air AM/FM radio broadcast signal made by a FCC licensed broadcaster over the Internet is not exempt, under section 114(d)(I)(A), from the digital performance right. Public Performance of Sound Recordings: Definition of a Service, 65 Fed. Reg. 77292 (2000). Recognizing the greater potential for displacement of sales, the Office noted that digital transmissions pose an "increased risk that a listener may make a highquality unauthorized reproduction of a sound recording directly from the transmission instead of purchasing a legitimate copy in the marketplace, a risk that is clearly greater when the recipient is receiving the transmission on a computer, which can instantly replicate and retransmit the transmission." Id. at 77294. In response to the Copyright Office action, the National Association of Broadcasters filed suit in federal court challenging both the Copyright Office's authority to promulgate the rule and the correctness of the ruling as a matter of statutory construction. Bonneville Int'l Corp. v. Peters, No. 01-408 (E.D. Pa. filed Jan. 25, 2001). The District Court rejected the broadcaster's position and granted summary judgment to Peters, the Register of Copyrights, holding that the Copyright Office had authority to issue its final rule and that the Office's rule was not just reasonable but it reached the same conclusion as the court would in the absence of its required deference to the Office after full examination of the statute, its legislative history, and congressional intent. Bonneville Int'l Corp. v. Peters, 153 F. Supp.2d 763 (E.D. Pa. 2001).

${ }^{41} 17$ U.S.C. sec. $114(d)(2000)$.

4217 U.S.C. sec. 114(d)(2)(A),(C) (2000). Section 114(d)(2)(B) grandfathers digital uses that existed prior to the DMCA under different terms. In order to be eligible for a statutory license, a webcast must meet a complicated set of conditions, which include limitations on the frequency and identification of the music performed by the service. These conditions seek to limit the license to those transmissions seen as least likely to substitute for record sales. See also 17 U.S.C. sec. 114(f)(2)(B)(i) (2000). For example, one condition on eligibility is that the transmitting entity not exceed the "sound recording performance complement," which restricts the number of songs from a recording or by an artist which may be played during any three-hour period. 17 U.S.C. sec. 114(d)(2)(B)(i), (j)(13) (2000).

4317 U.S.C. sec. 114(f)(2)(B) (2000).
} 
including whether the use of the service may substitute for or enhance the sales of phonorecords. $^{44}$

\subsection{Exclusive Rights}

Under section 114(d)(3), exclusive licensing authority is granted to the owner of the sound recording copyright (i.e., the record label) for downloaded and interactively streamed digital audio transmissions that are more likely to displace sales of physical records. Protected downloads can be permanent, temporary, or incidental to a stream. While the act grants copyright owners full rights to negotiate licenses, exclusive licenses cannot be binding for more than one year until the owner has granted at least five such licenses. This limitation recognizes the need for markets to congeal to establish reasonable competitive benchmarks and avoid lock-in. The limits of what constitutes an "interactive service" are not wholly clear. ${ }^{45}$

\subsection{Downloads}

Section 115 establishes compulsory mechanical licenses for secondary uses of musical compositions used in the traditional making and distribution of both hard copy phonorecords and digital phonorecord deliveries (DPDs). ${ }^{46}$ Compulsory mechanical licenses can be activated after a legitimate recording of a composition is distributed to the public. $^{47}$ The law specified starting fees for units sold of permanent DPDs that were equal to corresponding units in physical sales. ${ }^{48}$ Subsequent rates can be set through negotiation or, if necessary, arbitration. ${ }^{49}$

\footnotetext{
${ }^{44} 17$ U.S.C. sec. 114(f)(2)(B)(i)(2000). The panel is also to consider "the relative roles of the copyright owner and the transmitting entity in the copyrighted work and the service made available to the public with respect to relative creative contribution, technological contribution, capital investment, cost, and risk." Id. at sec. 114(f)(2)(B)(ii).

${ }^{45}$ The Copyright Office rejected in the year 2000 a petition that sought a clarifying amendment to the definition of "interactive" in the Office's regulations. Public Performance of Sound Recordings: Definitions of a Service, 65 Fed. Reg. 77,330 (2000). The Office decided that "a service does not become interactive merely because consumers may have some influence on the music programming offered by the service." While recognizing that uncertainty existed over "how much influence a consumer can have on the programming offered by a transmitting entity before that activity must be characterized as interactive," the Office concluded that it was neither necessary, desirable, nor feasible to try to resolve the uncertainty via regulation at the present time.

${ }^{46}$ A "digital phonorecord delivery" is each individual delivery of a phonorecord by digital transmission of a sound recording which results in a specifically identifiable reproduction by or for any transmission recipient of a phonorecord of that sound recording. 17 U.S.C. sec. 115(d) (2000).

${ }^{47} 17$ U.S.C. sec. 115(a)(1) (2000).

${ }^{48}$ For every digital phonorecord delivery made on or before December 31,1997 , the royalty rate payable with respect to each work embodied in the phonorecord shall be either 6.95 cents, or 1.3 cents per minute of playing time or fraction thereof, whichever amount is larger. 17 U.S.C. sec. 115(c)(3)(A)(i) (2000). For deliveries made on or after January 1, 1998, the royalty rate payable with respect to each work in the phonorecord shall equal the rate applied to physical reproductions (that is, the "Physical Rate").

${ }_{49} 17$ U.S.C. sec. 115 (c)(3) (2000). As with the compulsory license for the digital performance right, the ratesetting process involves two steps. First, voluntary, industry-wide negotiations to set rates to be adopted by the Copyright Office are encouraged. If these negotiations falter, any interested party can petition the Copyright Office to convene an arbitration proceeding to establish the fees. 17 U.S.C. sec. 115(c)(3)(B)-(F) (2000).
} 
In addition to distribution of permanent downloads, Section 115 also establishes a paradigm for rental, lease, or lending that could reasonably be used to establish license fees for temporary downloads and streaming services as well. ${ }^{50}$ As a percentage of sales revenues, the royalty paid for secondary compositions embedded in record rentals shall be equal to a corresponding percent of revenue garnered from the sale of the phonorecord. If applied to "digital renting" made possible by temporary download, Section 115(c) would fix copyright fees on prices in a symmetric manner and avoid distorting relative prices among competing delivery technologies. That is, if a compulsory license royalty accounts for $10 \%$ of the revenues of a permanent download, it should also equal $10 \%$ of the revenues of a corresponding temporary download.

\section{Downloads and Substitution}

We shall now construct an economic analysis of how copyright fees should be set for musical compositions embedded in sound recordings and permanent DPDs.

Permanent downloading of music is an attractive alternative to owning physical CDs in a number of key respects (Einhorn, 2002). Songs can be individually purchased, catalog choices are wider, digital technology enables instant product delivery, and storage on hard drive takes up less space. Portability is easier if digital files can be loaded to flash memory or virtual lockers, and digital technology enables personalized suggestions, advertising, and related electronic commerce. On the downside, downloads on hard drives are not yet fully compatible with home stereo equipment and the convenience of family room listening. This disadvantage will lessen if the industry can establish standards to accommodate $\mathrm{CD}$ burning, and users build out wireless local area networks that interconnect home entertainment appliances.

In addition to permanent downloads, it is also possible to make transmitted bits available for timed temporary storage (such as a week or month). Access terms may vary by price, number of permitted plays, duration of access, and the number of computers on which the work may be played. The resulting business model will enable record companies to distinguish different intensities of use and price accordingly.

Digital music will then be made available along a continuum of listener intensities that will further confound attempts to classify transmissions as reproductions or performances. While downloaded reproductions may generally be expected to displace or promote original sales of CDs and tapes, it is important to take seriously a large-scale substitution effect, as it may subvert the incentives of copyright. This assessment of effect would properly consider the displacement of both record sales and licensing opportunities for the copyright holder.

Certain reproductions or performances may displace or promote original sales. That is, they may have substitution and/or complementary effects. For example, a permanent download of tracks on a CD may displace the sale of the original record. By contrast, a sound recording performance in a record store may promote the sale of originals, and that performance is now exempt from copyright liability. Because of the presence of both these kinds of effects, as an a priori matter it is difficult to predict sometimes whether a practice of reproduction or performance increases or decreases sales (Kurlantzick and Pennino,

${ }^{50} 17$ U.S.C. sec. $115(c)(4)(2000)$. 
1998, p.497). However, as a matter of copyright policy, a large-scale net substitution effect would have to be taken seriously, as it implies that the practice(s) may subvert the incentives of copyright to the point where less works than socially desirable are being produced and marketed.

In judging the potential for sales displacement and its implications, policy makers must attend to the risk of distorting relative prices of two music products that are substitutes for one another. Consider CDs and permanent downloads. A percent charge of $\mathrm{X}$ is placed on the first and a higher charge of $\mathrm{Y}$ on the second. The higher charge on downloads creates an incentive to substitute to the other. The result is that everyone who values the second good at more than $\mathrm{X}$ but less than $\mathrm{Y}$ will not purchase one, an inefficient outcome (see, for example, Polinsky, 1989, pp.119-20) Some consumers are deterred by the higher price of the product because of the charge from buying the product at all. As a result, some resources that would have produced the second good are now directed to other goods. But these goods are less valuable in the opinion of consumers. The consumers substitute a product that must be inferior, else they would have made the substitution before the charge was imposed. This shift to a less preferred choice is economically inefficient. ${ }^{51}$ If retail sales and DPDs are substitutes for one another, it would be economically efficient to fix equal percent charges on both in order to avoid price distortion.

As a business matter, music publishers who exclusively control first-time mechanical rights for a composition can be expected to hold for some reasonable balance on relative prices. More practically, they might assess equal unit charges on sold tracks in CDs and digital downloads. By imposing equal unit charges, they would recognize that a digital download may displace the sale of the same songs and endeavor to "make whole" the publisher and writer regardless of which is chosen. Though not theoretically perfect (relative price ratios can be distorted a bit if unit charges are set equal to one another), the practice would preserve a reasonably efficient relationship between relative prices and is fairly well justified.

For second reproductions, where compulsory licenses can be utilized, composition rights for physical sales and permanent DPDs are now set at the same unit price. That price is the larger of 7.55 cents per song or 1.45 cents per recording minute. ${ }^{52}$ As noted, the rights owners are made whole regardless of which option is chosen. Compulsory licenses for temporary downloads are set at the same percentage of implicated sales revenues as for permanent. This arrangement more directly establishes a price symmetry for temporary and permanent mechanical rights.

\footnotetext{
${ }^{51}$ Accordingly, efficiency concerns dictate that copyright fees reflect the value of process neutrality and be designed to minimize substitution effects.

${ }^{52}$ Presumably, the Copyright Office action in establishing identical compulsory fees for imprints of musical composition recorded in both media involves a recognition that digital downloads may displace the sales of the same songs imprinted on original CDs. As digital phonorecord deliveries are the functional equivalent of a reproduction and distribution of both the sound recording and the embodied musical composition, transmitters of transmissions which are deemed to be such deliveries must satisfy the compulsory licensing requirements for the delivery of the musical work as well as obtain a voluntary license for the delivery of the sound recording. Indeed, since copyright owners have the same protection against infringement via digital phonorecord delivery as they have against physical phonorecord distributions, an unauthorized digital phonorecord delivery implicates the reproduction/distribution rights of both the sound recording and musical work copyright owners and potentially implicates the public performance right of the musical work copyright owner and the digital performance right of the sound recording copyright owner.
} 
If the fees for the related reproduction rights of mechanical imprints and permanent downloads of music compositions are added in a balanced fashion, it would be economically inefficient to fix on DPDs additional copyright fees not assessed on retail sales. Nonetheless, this possibility exists, as a current contested question is whether permanent or temporary downloads constitute both a reproduction and a public performance, even if the recipient is unable to hear the song as the file is received. Pointing to the Copyright Act's definitions of "perform" and "publicly", ${ }^{33}$ performance rights advocates assert that all digital transmissions of music are public performances and therefore subject to copyright liability as such. ${ }^{54}$

If this position is accepted, the digital transmitter would need separate licenses for two complementary rights. Moreover, it would need to negotiate with the publisher for the mechanical component, and the three PROs for the coincident performance right. By imposing additional costs of negotiation and administration, "double dipping" through the performance right here would present an economically inefficient burden on providers of digital phonorecords.

In August 2001, the Copyright Office considered the matter in a report issued in connection with its responsibilities under section 104 of the DMCA. ${ }^{55}$ It urged that DPDs be exempt from the performance right:

To the extent that such a download can be considered a public performance, the performance is merely a technical by-product of the transmission process that has no value separate from the value of the download ... Demanding a separate payment for the copies that are an inevitable by-product of that activity appears to be double-dipping and is not a sound equitable basis for resisting the invocation of the fair use doctrine."

The Report's suggested solution, which places copyright charges for DPDs under the exclusive domain of mechanical rights, ${ }^{56}$ can be expected to produce a reasonably balanced outcome and is therefore economically sound.

\section{$6 \quad$ Interactive Streaming}

Interactive streaming enables digital users to choose music tracks in "jukebox" play that involves personal choice. In combining choice with transmission, interactive streaming preserves the option value of owned discs without need for storage in cabinets or hard drives. Furthermore, interactive streaming widens subscriber choice to access entire

\footnotetext{
5317 U.S.C. sec. 101 (2000).

${ }^{54}$ See, for example, ASCAP, Frequently Asked Questions About Internet Licensing, at http://www.ascap.com/weblicense/webfaq.html (last visited December 13, 2001). The basic copyright question with respect to download transmissions is whether these transmissions constitute not only a reproduction of the transmitted music but also a public performance by digital transmission, even if the recipient is unable to hear the song as the digital music file is being received. If so, the transmitter also requires permission from the owners of the public performance rights. Interestingly, the Clinton Administration's White Paper, which is quite generous to copyright owners in its interpretation of copyright law in the Internet setting, concludes that such a transmission clearly does not constitute a public performance. See Reese (2000).

${ }^{55}$ U.S. Copyright Office, DMCA Section 104 Report (2001).

${ }^{56}$ This exemption from the performance right is justified because separate administration and double-dipping remain a problem when the end user seeks to secure a copy rather than a real time performance, as the delivery of the copy could be considered a public performance as well as a digital distribution of the copy. Accordingly, the reproduction right is the only one that should be paid for. See Liu (2001).
} 
catalogs of music at a moment's notice and to identify preferred tracks that can subsequently be downloaded. The relative market value of streaming will increase further as music transmission goes wireless and users enjoy greater portability. Finally, streaming may better serve the interests of rights owners as well, as users cannot readily pirate temporary reproductions made during the course of a stream.

Any service made available by interactive streaming may at times displace or promote individual downloads and retail sales. Digital technology permits audiophiles to instantly access music from signed and unsigned artists without needing to visit local record stores. Thus, while interactive streaming may offer subscribers access to entire catalogues in a manner that could displace needs for permanent ownership, it also may provide free streams to promote live events and product made available by the same artist. Nonetheless, the displacement threat of streaming seems substantial and will be taken as primary. Having exclusive performance rights, ${ }^{57}$ a label may control interactive streaming of its tracks and price access as it sees fit. Therefore, a label can price the "making available" of retail sales, downloads, and interactive streams in a manner that internalizes all economic tradeoffs. ${ }^{58}$

However, the technical process of streaming requires that the receiving device temporarily store as an incidental reproduction a few seconds of transmitted data in a segment of random access memory (RAM) that is allocated as a "buffer" for audio performance. ${ }^{59}$ A conflict consequently arises regarding the proper legal handling of the buffer reproduction that is made necessary to hold the bits that are part of a streamed transmission. The mechanical rights organizations assert that all Internet transmissions involve physical reproduction in random access memory, however temporary, and therefore implicate reproduction rights. ${ }^{60}$

The Copyright Office's Section 104 Report, however, argues that the temporary buffer copy of a licensed digital transmission should be non-infringing ${ }^{61}$ and recommends that Congress enact legislation to establish an explicit exemption. ${ }^{62}$

\footnotetext{
${ }^{57}$ As established in sections 106 and 114 of the Copyright Act, sound recordings used in interactive streaming are protected by an exclusive public performance right.

${ }^{58}$ Thus the danger of unbalanced copyright fees is avoided for sound recordings used in interactive streamings, as record companies will have reason to avoid distorting relative prices and to internalize all economic tradeoffs involving the related prices of substitute services.

${ }^{59}$ The receiving device collects in the RAM buffer a few seconds of data to guard against interruptions or delays due to line congestion or slow Internet connections. More particularly, when a user requests transmission of streamed transmissions, the software on the user's receiving device communicates with the transmitting server and determines, given the quality of the media and the speed of the transmission, how many seconds of data should be stored in the receiving device's RAM buffer before beginning playback to the user. The data in the RAM buffer can not be accessed for other purposes within the receiving device. Once performed, the transmitted data leave the buffer permanently and can not otherwise be stored in a digital copy on the device. The buffer has no utility to the consumer other than to facilitate these performances. As no copy of the recording remains stored on the computer, if the user wants to hear the streamed recording again, he must once more contact the website and request that it transmit the file again. ${ }^{60}$ See, e.g., Joint Reply Comments on Copyright Industry Organizations, Report to Congress Pursuant to Section 104 of the Digital Millennium Copyright Act 8-13 (Sept. 5, 2000).

${ }^{61}$ The Office believes that there is a strong case that the making of a buffer copy in the course of audio streaming - a copy made solely to enable performance of the musical work and sound recording - is a fair use. Recognizing the uncertainty attending application of the case-by-case fair use defense, however, the Office recommends that Congress enact legislation amending the Copyright Act to preclude any reproduction right liability with respect to temporary buffer copies that are incidental to a licensed digital transmission of a public performance of a sound recording and any underlying musical work.
} 
Buffer copies have no independent economic significance. They are made solely to enable the performance ... The same copyright owners [i.e., publishers and songwriters] appear to be seeking a second compensation for the same activity merely because of the happenstance that the transmission technology implicates the reproduction right, and the reproduction right of songwriters and music publishers is administered by a different collective than the public performance right.

The Copyright Office's recommendations mirror provisions in a recent European Union (EU) Directive, which exempts transient copies from the reach of the reproduction right.

If enacted, the report would put the "making available" right under two different administrative regimes. Interactive streaming would be under the domain of the performance right, and downloading under the domain of the mechanical. There would be little possibility of coordinating disparate rights under split administrations.

From an economic perspective, this compromise, though superior to a regime of double-dipping, is inefficient. Much as with temporary downloads, the Copyright Office should assign streaming rights in a manner that is likely to avoid distorting relative prices among subscribers. Efficiency in relative pricing and regulatory administration can be more reasonably expected if all of the "making available" transmissions were integrated under the same domain. Moreover, additional savings in negotiation would result as digital providers negotiate for mechanical rights in "one stop negotiations" that avoid a second round for performance licenses.

As a final competitive advantage of this proposed structure, mechanical royalties are now paid to individual publishers, who pass to respective writers shares that can be bilaterally negotiated. When publishers and writers so negotiate, individual publishers can commit to more specific contract terms and generally compete for writers. Among the desirable features of publisher negotiations, advances may share risk more equitably. Detailed contract negotiation is less practical in performing rights, where agencies must administer contracts for millions of songs. Indeed, performing rights societies now generally split royalties 50/50 between publisher and writer. Accordingly, by routing payments through publishers, writers may have greater capacity to negotiate individualized contracts that avoid many of the legal difficulties they now face.

\section{$7 \quad$ Non-interactive Streaming}

We now turn to the remaining major digital transmission technology, non-interactive streaming uses that are eligible for a compulsory sound recording license. 63 "Webcasting" provides "broadcast-like" services that will greatly expand delivery of music to new audiences, regions and countries. Though it is uncertain what business models will prove most viable, advertising revenues, e-commerce, and the sales of market data can be expected to figure prominently.

As an equitable matter, songwriters are appropriately compensated for performance rights on broadcast radio and television as their music provides the incentive for people to listen and advertisers to spend money to reach them. The collection amount is now proportional to the sales of advertising. For example, blanket fees for radio broadcast uses at ASCAP are set at $1.615 \%$ of station advertising revenues less reasonable deductions. ${ }^{64}$

\footnotetext{
${ }^{62}$ U.S. Copyright Office, DMCA Section 104 Report, at xxiii-xxvii, 132-46.

${ }^{63} 17$ U.S.C. sec. 114(d)(2) (2000). Eligible licensees may, instead of utilizing the compulsory license, choose to negotiate other alternative arrangements with individual content owners.

${ }^{64}$ ASCAP, Local Station Blanket Radio License, at 8(A)(2), available at http://www.ascap.com/licensing/
} 
Webcasters then can reasonably pay a percentage of their earned revenues for performance rights. The revenue base for license fees should include advertising revenues, as well as other commercial services not directly related to the sale of music. The appropriate percentage amount would depend on usage and the likelihood that some users of non-interactive streaming will utilize software to capture preferred streams for permanent download, thereby displacing sales, or otherwise invest listening time that might otherwise be used with subscription services.

More openness in this industry could be had if collections for performance rights were removed from the jurisdiction of the Federal Rate Courts and reassigned to the Copyright Office, with license fees determined at Copyright Office Hearings. Under its present governance structure, the Copyright Office can issue Notices of Inquiry and Proposed Rulemaking that would invite comments from all affected parties with regard to any relevant matter. Furthermore, the Copyright Office could grant equal legal standing to any party in administrative hearings designed to consider rule changes and set license fees. This change would particularly address the legal concerns of copyright owners (publishers and writers), who now lack legal standing on some issues in the Rate Courts.

As discussed by Einhorn (2001), there is no economic need for more than one collection agency to administer the performing right for musical compositions. Consequently, an appointed agent for digital collections must be designated in some manner, including possibly a consortium operated by or rotated between the three existing PROs. As the Justice Department suggested, ${ }^{65}$ digital technologies now exist for the monitoring of webcast performances that could enable stream counts and surveillance. Such monitoring could be done by an independent party, such as Sound Exchange, the monitoring authority of the recording labels, or Music Reports Inc., which is an independent monitoring authority that now collects music use data on broadcast radio and television, and which would report results back to the collection agency. With monitored reports, the collection agent would apportion the collected performance royalties to individual rights owners in an agreed manner that may consider both the number of streams and listeners of a particular composition.

\section{Conclusion}

We summarize our discussion as follows. We advocate a two-tier structure for the administration of copyright in digital audio transmissions of musical compositions. First, composers and publishers of songs would be compensated for permanent and incidental uses related to the reproduction of their works in downloads and interactive streaming services. Rates would be designed to ensure a rough percentage parity among the services. Such symmetrical benchmarks are now in effect in section 115 regarding rates for temporary downloads.

Performance licenses would remain in effect as a means for garnering revenues from advertising and other services unrelated to the direct sale of music. Performance licenses can be applied to webcasters, as well as interactive services that supplement their music provision with other services. These licenses are appropriately administered by the

radio/Blanket_Radio_License.pdf (last visited March 3, 2002).

${ }^{65}$ See supra note 23 and accompanying text. 
Copyright Office, with fees collected by one appointed agent, and monitored with a digital system that assigns to each party a designated share of the collected pot of royalties.

\section{$9 \quad$ References}

Bard, Robert and Lewis Kurlantzick (1974) "A Public Performance Right in Recordings: How to Alter the Copyright System Without Improving It," George Washington Law Review, 43: 152-238.

Einhorn, Michael. (2001) "Intellectual Property and Antitrust: Performance Rights in Broadcasting," Columbia-VLA Journal of Law and the Arts, 24: 49-368.

Einhorn, Michael. (2002) Music Licensing in the Digital Age. In Ruth Towse (ed), Copyright in the Cultural Industries. Edward Elgar Publishers.

Ginsburg, Jane. (2001) "Can Copyright Become User-Friendly? Essay Review of Jessica Litman, Digital Copyright," Columbia-VLA Journal of Law and the Arts, 25: 71-89.

Ginsburg, Jane. (2002) From Having Copies to Experiencing Works: the Development of an Access Right in U.S. Copyright Law. In Hugh Hansen (ed), U.S. Intellectual Property: Law and Policy. Sweet and Maxwell.

Law: Law and Policy, edited by Hugh Hansen.

Karjala, Dennis. (2001) "The Digital Dilemma: Intellectual Property in the Information Age," Jurimetrics Journal 41: 527-37.

Kurlantzick, Lewis and Jacqueline E. Pennino (1998) "The Audio Home Recording Act of 1992 and the Formation of Copyright Policy," Journal of the Copyright Society, 45: 497545.

Leach, Eric. (2000) "Everything You Always Wanted To Know About Digital Performance Rights But Were Afraid To Ask," Journal of the Copyright Society, 48: 191291.

Leaffer, Marshall. (1999) Understanding Copyright Law. Matthew Bender \& Co.

Lemley, Mark. (1997) "Dealing with Overlapping Copyrights on the Internet," University of Dayton Law Review 22: 547-85.

Lessig, Lawrence. (2001) The Future of Ideas. Random House.

Liu, Joseph. (2001) "Owning Digital Copies: Copyright Law and the Incidents of Copy Ownership," William and Mary Law Review, 42: 1245-1366.

Nimmer, David. (2000) "Ignoring the Public, Part I: On the Absurd Complexity of the Digital Audio Transmission Right," UCLA Entertainment Law Review, 7: 189-265. 
Polinsky, Mitchell. (1989) An Introduction to Law and Economics. Little, Brown and Company.

Reese, R.A. (2000) "Copyright and Internet Music Transmissions: Existing Law, Major Controversies, Possible Solutions," University of Miami Law Review, 55: 237-273.

Towse, Ruth. (1999) "Copyright and Economic Incentives: An Application to Performers' Rights in the Music Industry," Kyklos 52: 369-390. 